\title{
EchoGéo
}

45 | 2018

Déclinaisons géographiques du changement social en Iran

\section{Crossing Gates, Walls and Gardens: The Evolution of Tehran}

Interview with Hamed Khosravi, conducted via email, in August 2018.

\section{Hamed Khosravi and Sepideh Soltaninia}

\section{(2) OpenEdition}

Journals

Electronic version

URL: https://journals.openedition.org/echogeo/16035

DOI: 10.4000/echogeo.16035

ISSN: 1963-1197

\section{Publisher}

Pôle de recherche pour l'organisation et la diffusion de l'information géographique (CNRS UMR 8586)

\section{Electronic reference}

Hamed Khosravi and Sepideh Soltaninia, "Crossing Gates, Walls and Gardens: The Evolution of Tehran", EchoGéo [Online], 45 | 2018, Online since 05 November 2018, connection on 10 August 2021. URL: http://journals.openedition.org/echogeo/16035 ; DOI: https://doi.org/10.4000/echogeo.16035

This text was automatically generated on 10 August 2021.

EchoGéo est mis à disposition selon les termes de la licence Creative Commons Attribution - Pas d'Utilisation Commerciale - Pas de Modification 4.0 International (CC BY-NC-ND) 


\title{
Crossing Gates, Walls and Gardens: The Evolution of Tehran
}

Interview with Hamed Khosravi, conducted via email, in August 2018.

\author{
Hamed Khosravi and Sepideh Soltaninia
}

1 In their 2017 book, Tehran: Life Within Walls, Hamed Khosravi, Amir Djalali and Francesco Marullo study Iran's capital by examining how its contemporary forms and ancient territory are innately political creations. They explore the history of Tehran from before the presence of settlements to the eve of the Islamic Revolution of 1979.

2 The authors begin by describing how the city came to exist in a desert, highlighting how nomadic knowledge helped create Tehran. The book then examines the establishment of the city's quarters, walls and gates, studying how the city came to be ruled and organized, as well as how it was constructed and torn down. The authors also highlight Western infrastructural influences throughout the $20^{\text {th }}$ century, such as boulevards, housing complexes and suburbs. Ultimately, they illustrate that, despite attempts to control or dictate the lives of Iranians through urbanization and new housing typologies, the government was unable to repress opposition and the desire for change.

3 In the Afterword of Tehran: Life Within Walls, Michiel Riedijk, Chair of Architecture and Public Building at the Faculty of Architecture and the Built Environment at the Delft University of Technology, asks both the authors and the reader, "But what exactly is that "life within walls?"' The question, posed at the end of a book, serves as a jumpingoff point for readers. Armed with the themes and historical analyses provided by the book, the reader can now explore their own definition of walls, both in the context of the Iranian capital and other cities they may inhabit.

4 In an attempt to provide some answers to Riedijk's question, the book ends with six reflections from various architects on the future of architecture in Tehran. The reflections expand on the themes discussed in the book, presenting new detailed visions of forms and spaces in the Iranian capital, including gardens for the middle class, one-room offices, and a living-working space for the bazaar's logistic workers. Most importantly, the appendix helps ground the book in the present and future, 
showing the reader several potential ways in which forces existing in Iranian history may continue to shape the country's most populous city.

The book was, in large part, born from Hamed Khosravi's doctoral dissertation entitled "Camp of Faith: On Political Theology and Urban Form". Khosravi, who was born in Paris to Iranian parents and raised in Tehran, spent several years working as an architect before embarking on his doctoral studies at the Berlage Insititute and, later, TU Delft. His dissertation and the book are attempts to explore the city of his childhood, which continues to change rapidly. In this interview, he explores some of the central themes of the book, with a particular focus on how they relate to the city's future.

6 - Sepideh Soltaninia (SS). The book discusses the relationship between nomadic culture and the state, especially with regard to the construction of carvanserais. Do you believe there are any nomadic or indigenous influences today as Tehran further urbanizes and expands? If so, what are these influences and what role do they play in the future organization of the city? Is it still true, as it is written on page 35 , that "the state needs the presence of autonomous initiatives and nomadic life"?

7 - Hamed Khosravi (HK). The relationship between nomadic forces and the state has been discussed in a historical perspective, in shaping particular architectural typologies or urban form. Whereas in this reading the urban form could be read as a result of such dialectical relationship, today it is rather the economic rationale and the market that generates urban form and fosters urbanization. However, nomadic forces are still active; seasonal workers, students, freelancers, artist, immigrants, whom all could be framed under precarious forms of live, are not only occupying and activating the generic fabric of the city, but are also gradually making changes in the social, spatial, and economic structure of particular neighbourhoods.

8 Although today's social housing projects of the city-which are mushrooming in the peripheries of the city-could be seen as new caravanserais for the nomadic work forces, what would be perhaps more interesting is to see how contemporary nomadic forces are changing the city from within, and how the city and its architecture can adapt itself to this way of living.

In a political reading of such a concept, we could see nomadic forces as the initiators of movements, be it social, political, or economic. However, the state is, by definition, the representative of the static and stabilizing forces. Nomadic life needs security, and a legitimate state is shaped democratically. The balance between the two would eventually result in an evolutionary and dynamic society. However, any misbalance, as is often the case, would lead to rupture.

9 - SS. I found the history of the bazar fascinating. You write on page 37 that "even today, a full survey of the bazar's spaces and inhabitants continues to be lacking". Can you elaborate on what such a survey would reveal about society, the politics and economics of Iran, and the organization of Tehran today?

10 - HK. The bazar is a semi-formal, yet very strong, economic engine of the city. In particular, the bazar of Tehran has a much larger effect in distributing goods and setting prices throughout the country. It is still running with some sort of guild-like organisation that somehow escapes the official state-controlled market. Such relative independence allows the bazar and its businessmen to control their own flows of capital, goods, and work forces. Thus, they potentially have enough power to manipulate the economic flows of the country. Although on one hand the bazar has 
been mostly aligned with the state since the 1979 Islamic Revolution, on the other hand, its power is weakened by the presence of global franchised brands. However, still the very economic, social, and even spatial structure of the bazar, has turned it to a potential threat to any ruling regime.

11 - SS. On page 47 you write that the "the garden literally provides the minimum requirement for urbanization". Is this still true of Tehran and other Iranian cities? If so, how are gardens being incorporated in the urbanization of Tehran today? If not, what is the cultural and social impact of expanding Iranian cities that lack this unique feature of Iranian life?

12 - HK. Historically the garden was part of an extensive territorial project to bring water from the foot of the mountains to the plains suitable for any kind of settlement. Being the end point of Qanat system, the garden had marked a piece of land to be irrigated by the amount of water that can be extracted from the underground channels. This literally means that gardens used to have an infrastructural role linked to the foundation, development, and expansion of the Iranian cities, including Tehran.

of course, this was a historical process very much linked to the hydrological technologies and construction techniques. Today, other factors, such as economic, political, or social, are much more decisive in shaping of the cities.

13 Traces of those gardens that have been incorporated in shaping of today's urban form of the city could be seen in the urban grid of Tehran and the orientation of the plots, that are mostly aligned with the underground water channels. In particular, these allotment patterns are visible in the area adjacent to the former wall of the city on the North, West and East parts.

14 We have to remember that the book looks at the gardens through a very particular lens, reading them within 'geopolitical' framework of execution of power in specific territories. However, the cultural, environmental, or productive aspects of gardens have always been inseparable characteristics of those settlements, tied into the ways in which those spaces were lived. It would be a naïve assumption if we would try to apply such factors on contemporary modes of urbanization, wherein capital accumulation, circulation, and of course the politics of planning take over the others.

15 - SS. The book also touches on how architecture has influenced the role of women as housewives and as workers throughout the history of Iran. How integral do you think spaces are today in defining women's roles (especially with the advent of the internet)? How are spaces defining women's roles in Iran today?

16 - HK. Yes, indeed this was one of the core arguments of the book in revisiting Tehran's contemporary architecture. The third chapter discusses the mutual relationships between the domestic space and the form of life, and in particular women, as the fundamental subjects of the housing projects, conditioning and being conditioned by the spaces of the house. Such relationships still exist today and have become even more present in repositioning women's role in the house and in society. Thanks to the recent market-driven architecture of the city, domestic spaces have turned to generic spaces of working and living; a rather gender-neutral fluid space wherein the traditional boundaries between male and female spaces cease to exist. It inevitably provides more opportunities for women to take back control of spaces.

The same formula works even smoother in cyberspace. The generic-ness of the internet 
leaves room for more gender-equal opportunities that would eventually lead to more social, political, and economic activities.

What is discussed in the book is one of the most fundamental changes, driven by the leftist agenda-which was later countered by an American project-to liberate women from the traditional housewife tasks and to activate them as the forgotten half of the political forces of society. However, such a relationship between the space and women's role in society is not the most direct and has changed throughout history. It has been altered by many internal and external factors, each of which requires a separate research and study.

18 - SS. Can you please tell me a little about your relationship with the city of Tehran (i.e. where you born and/or raised there? If not, when was the first time you visited? What sparked your interest in the city?) In the course of your research, did any information you discovered change or challenge how you view of Tehran? How has in-depth research into the city changed your perspective of it?

19 - HK. I was actually born in Paris, France from Iranian parents. We went back to Tehran when I was less than three years old. I grew up in the city and lived in many neighbourhoods. Those years were not the most peaceful ones; I witnessed 8 years of the destructive war with Iraq and a city was destroyed and reconstructed in front of my eyes.

20 I became interested in architecture and have done most of my undergrad and postgraduate projects about the city. I also practiced architecture for several years before starting my doctorate research. As an architect, I did not have a convincing answer to 'what to build' and 'why to build', whenever I was asked to design a project. What struck me in developing those projects was how little is explored and written about the history of the city that is changing face in a much faster speed compared to other metropolises of its size.

21 A combination of my interests in the city that I grew up in, the experience of many lived spaces, and the lack of in-depth knowledge about the city, motivated me to leave my practice in Tehran and to follow up my doubts and questions in a doctoral research at the Berlage Institure and later Delft University of Technology; a research that, although has been concluded and presented in many forms, still moves on.

22 - SS. The book discusses the construction, and later destruction, of several gates in Tehran. Is there a specific gate (still existing or demolished) that you find particularly interesting? If so, what fascinates you about it?

23 - HK. All the gates of the walled city are demolished between 1927-33. Each gate had its own characteristics in terms of spatial configuration and decoration. Even the two sides of each gate were different from each other. What fascinates me specially about the latest 13 gates of the city is not their particular architecture, but rather their very purpose. They did not have any function! At the time of their construction, the city did not have any need for a defensive structure. The gates were a symbolic representation of what was to be defined as the territory of power, circumscribed and outlined by a wall and gates.

24 - SS. In the process of writing this book (or your dissertation which inspired the book), did you re-evaluate your definition of 'walls'. If so, what insight did you gain about the concept of walls in general and in Iran specifically? 
25 - HK. Yes, indeed the redefinition of the wall shaped the foundation of my dissertation and later the book.

Today's architectural discourse, through its commitment to the global economy, often highlights the negative role of borders and divisions in the formation of good and productive urban development. In this sense, walls have been addressed as emblems of failed urbanism, causing segregation, separation and interruption. In fact, the very project of the modern city has been to fade these borders and walls by which the economy of the city has historically been produced. This process not only affects the way cities are planned, designed and constructed, but also abandons the collective dimension of life: citizenship, which is political by definition. The wall could be read as a counter-project: among the fundamental elements of architectural form, wall comes before the rest. The primary purpose of wall is to establish a relationship; association comes before separation.

\section{AUTHORS}

\section{HAMED KHOSRAVI}

Hamed Khosravi is an architect, researcher, and Diploma Unit Master at the Architectural Association School of Architecture, London. He recently published:

- Khosravi H. (ed.), Djalali A., Marullo F., 2018. Tehran: Life Within Walls. A City, Its Territory, and Forms of Dwelling. Berlin, Hatje Cantz. 220 p.

- Khosravi, H., 2018. The Nomos of the Sea: Pirates, DJs, Hackers, and the Architecture of Contingent Labor. The Avery Review [En ligne], 29. http://averyreview.com/issues/29/nomos-ofthe-sea

- Khosravi, H., 2015. The Multiple Lives of Gabriel Guevrekian. AA Files: Annals of the Architectural Association School of Architecture, $\mathrm{n}^{\circ} 71$, p. 50-63.

\section{SEPIDEH SOLTANINIA}

Sepideh Soltaninia, Master in Public Affairs Candidate at Princeton University. 